\title{
Article \\ A Comparative Study of Biocompatibility in Rat Connective Tissue of a New Mineral Trioxide Compound (Theracal) versus MTA and a Bioactive G3 Glass
}

\author{
Jesús Mena-Álvarez ${ }^{1, *(D)}$, Cristina Rico-Romano ${ }^{1}$, Carlos Gutiérrez-Ortega ${ }^{2}$, Pablo Arias-Sanz ${ }^{3}$ and \\ Javier Castro-Urda ${ }^{4}$
}

check for

updates

Citation: Mena-Álvarez, J.; Rico-Romano, C.; Gutiérrez-Ortega, C.; Arias-Sanz, P.; Castro-Urda, J. A Comparative Study of Biocompatibility in Rat Connective Tissue of a New Mineral Trioxide Compound (Theracal) versus MTA and a Bioactive G3 Glass. J. Clin. Med. 2021, 10, 2536. https://doi.org/10.3390/ jcm10122536

Academic Editor: Federico Foschi

Received: 7 May 2021

Accepted: 3 June 2021

Published: 8 June 2021

Publisher's Note: MDPI stays neutral with regard to jurisdictional claims in published maps and institutional affiliations.

Copyright: (c) 2021 by the authors. Licensee MDPI, Basel, Switzerland. This article is an open access article distributed under the terms and conditions of the Creative Commons Attribution (CC BY) license (https:// creativecommons.org/licenses/by/ $4.0 /)$.
1 Department of Endodontics, Faculty of Dentistry, Alfonso X El Sabio University, 28691 Madrid, Spain; cromaric@uax.es

2 Department of Epidemiology, Central Defense Hospital "Gomez Ulla”, 28047 Madrid, Spain; cgutort@oc.mde.es

3 Veterinary Service, Central Defense Hospital “Gomez Ulla”, 28047 Madrid, Spain; parisan@oc.mde.es

4 Department of Veterinary, Faculty of Veterinary, Alfonso X El Sabio University, 28691 Madrid, Spain; j.castro.u@gmail.com

* Correspondence: jmenaalvarez@gmail.com or jmenaalv@uax.es

\begin{abstract}
The aim of this paper was to assess the differences in tissue response to implantation during 15, 30 and 45 days in the subcutaneous connective tissue of Wistar rats from three biomaterials: Angelus MTA ${ }^{\circledR}$, Theracal LC ${ }^{\circledR}$, and Angelus MTA ${ }^{\circledR}$ to which $25 \%$ bioglass G3 was added. Twentyfour Wistar rats were used, the materials were inserted into the rat's dorsal area in silicone tubes $5 \mathrm{~mm}$ long by $1.5 \mathrm{~mm}$ diameter. Histological reaction was assessed at 15, 30, and 45 days after implantation. They were then stained with hematoxylin eosin and evaluated by two observers. Data were analyzed using Fisher's exact test and Mann-Whitney's U test was used to determine the association between variables. Angelus MTA induced the formation of dystrophic calcifications twice as much as Theracal LC $(p<0.05)$. The addition of G3 did not affect the greater or lesser occurrence of calcifications $(p>0.05)$. Theracal LC and MTA plus G3 caused an inflammatory reaction, which was chronic at 15 days and decreased in intensity, almost disappearing after 45 days. Theracal LC, as well as Angelus MTA plus G3, were well tolerated when implanted in the subcutaneous connective tissue of rat. Histologically, no inconvenience was found for the use by direct contact of Theracal LC, and the mixture of MTA with $25 \%$ bioactive glass G3, in the tissue of Wistar rats.
\end{abstract}

Keywords: mineral trioxide; G3 glass bioactive; Theracal; root-end sealers; endodontic surgery

\section{Introduction}

Endodontic microsurgery is often the last option when non-surgical retreatment fails, is unfeasible or unlikely to improve the initial endodontic treatment. In particular, only surgical intervention may resolve cases involving a persistent lesion (microbial infection) with etiology related to complex canal anatomy for this reason.

Root-end filling materials in endodontic microsurgery have evolved over time. However, these materials have the drawback of suffering from corrosion, electrolysis, expansion and coloration. They also present filtration problems, sealing deficiencies and marginal adaptation, show difficulties in their handling, the alteration of their setting in the presence of humidity and toxicity to vital tissues [1].

Microorganisms play an essential role in periapical disease [2], so the antibacterial properties of these materials are essential when assessing their suitability. The aim of these materials is to achieve an airtight seal after the resection of the apical root zone [3], sealing the communication between the periapical tissue and the root canal of the tooth. The root-end filling materials will be in direct contact with the periapical tissue, so they must be biocompatible [3] in order to prevent any response that conditions the failure of endodontic 
therapy [4]. The four classic methods that have been used to study the biocompatibility of materials have been: the evaluation of biocompatibility, placement of subcutaneous implants, placement of intraosseous implants, and in vivo evaluation of the periradicular tissue reaction in human subjects [5].

Mineral trioxide aggregate (MTA) has been used as a root-end filling material since the beginning of its presentation and its biocompatibility has been extensively analyzed [4,6-10].

Theracal LC ${ }^{\circledR}$ (Bisco Inc, Schamburg, IL, USA) is a material used in pulp coatings. It is a light-curing, resin-modified calcium silicate cavity liner designed to act as a barrier [11]. Theracal LC ${ }^{\circledR}$ is composed of $45 \%$ Portland cement type III, $10 \%$ radiopaque material, $5 \%$ fumed silica (hydrophilic thickening agent), and 40\% resin (it contains different hydrophobic monomers and hydrophilic monomers) [12]. Nor is there bibliography that analyzes the biological properties of Theracal $\mathrm{LC}^{\circledR}$ as a root-end filling material, although the rest of its properties have been analyzed [12-19]. This material is light-curing and improves the two main disadvantages of MTA, which are the setting time and the difficulty in handling.

Bioactive glasses have evolved to the fourth generation or P2O5-free bioglasses. The improvements of the fourth-generation bioglasses open the door to the development of new applications in the dental field, such as periodontics, surgery, implantology, prosthetic rehabilitation and in endodontic treatments. Among the bioglasses is G3; it is a sodium-calcium glass (soda-lime) similar to Hench's glass, but is free of phosphate, with a composition SiO2-Na2O-Al2O3-CaO-B2O3. López-Píriz et al. [20] used G3 to coat implants that they placed in Beagle dogs, observing improved periodontal health. The authors state that G3 bioglass is capable of preventing bone resorption around the implanted material. Studies with G3 impellers implanted in the jaws of Beagle breed dogs show that the rate of resorption of these fourth-generation glasses, for a porosity of $17 \%$ of the total weight, is adapted to the rate of bone growth. Not only is there bone growth in the resorption space of the G3 bioglass, but the histological sections demonstrate a cellular invasion within the porosity of the rim [21]. If we added it to other materials, the biocidal capacity of MTA could be strengthened, and its chemical and mechanical properties would be improved.

The aim of this study was to compare the biocompatibility of MTA Angelus ${ }^{\circledR}$ (Angelus, Londrina, Brazil), Theracal LC ${ }^{\circledR}$, and MTA Angelus ${ }^{\circledR}$ with G3 bioactive glass particles in a known ratio when the materials were implanted into the subcutaneous connective tissue of Wistar rats.

\section{Materials and Methods}

\subsection{Study Design}

The present research project has been approved by the Ethical Committee of the Animal Research Service of the Military Hospital Gómez Ulla of Madrid and also by the Environment, Local Administration and Territorial Organization Office of Madrid Autonomy (order number PROEX 065/17). In this project, we used 24 male Wistar rats with a weight ranging from 200 to $250 \mathrm{~g}$. Rats were housed in groups of two and given fourteen days to acclimate to the housing facility. Environmental conditions were a temperature of $20 \pm 2{ }^{\circ} \mathrm{C}$, humidity of $55 \pm 10 \%$. Animals were housed in cages and given access to rat maintenance food and water ad libitum. All sections of this report adhere to the ARRIVE (Animal Research: Reporting of in Vivo Experiments) guidelines for reporting animal research [18]. A completed ARRIVE guidelines checklist is included in Checklist S1.

For random allocation, we employed the EPIDAT 3.1 (Dirección Xéral de Saude Pública, Galicia, Spain) statistical package to generate a table of random numbers in three groups of eight rats and the control.

The determination of the sample size is based on similar research studies in which the tissue response to different biomaterials was studied, when these were implanted for short, medium and long periods [22-24]. 


\subsection{Anaesthesia}

The animals were anesthetized with a dissociative anesthetic, ketamine hydrochloride (Ketamidor ${ }^{\circledR} 100 \mathrm{mg} / \mathrm{mL}$, Karizoo S.A., Caldes de Montbui, Spain) at a dose of $75 \mathrm{mg} / \mathrm{kg}$ intramuscularly in combination with an alpha-2 agonist, medetomidine (Domtor ${ }^{\circledR} 1 \mathrm{mg} / \mathrm{mL}$, Orion Corporation, Espoo, Finland) at a dose of $0.5 \mathrm{mg} / \mathrm{kg}$ intramuscularly.

An opioid derivative, buprenorphine (Bupaq ${ }^{\circledR} 0.3 \mathrm{mg} / \mathrm{mL}$, (Karizoo S.A. Caldes de Montbui, Spain)), at a dose of $0.05 \mathrm{mg} / \mathrm{kg}$ administered subcutaneously, was used as intraand postoperative analgesic medication. All animals, as a prophylactic measure against possible infections, were administered intramuscularly a broad-spectrum antibiotic with bactericidal action on Gram-negative and Gram-positive microorganisms, enrofloxacin (Syvaquinol ${ }^{\circledR} 100 \mathrm{mg} / \mathrm{mL}$ (Laboratorios Syva, S.A.U. León., Spain)) at a dose of $5 \mathrm{mg} / \mathrm{kg}$ intramuscularly. Once anesthetized, they were placed in the prone position and immobilized on a cork board on a surgical table.

\subsection{Surgical Protocol}

The rats were shaved along the back and the lines where the incision would be made for the implantation of the biomaterials were marked equidistantly. Prior to the incision, the marked areas were cleaned and disinfected with povidone iodine (Betadine ${ }^{\circledR}$ dermal solution $10 \mathrm{~g} / 100 \mathrm{~mL}$ (Meda Pharma S.L., Madrid, Spain).

Four $10 \mathrm{~mm}$ incisions were made with a \#15 scalpel blade (Surgical Disposable Scalpel \# 15, Aesculap, Braun, Tuttlingen, Germany). Next, with blunt-tipped dissection scissors (Tekno 8365, Tekno Medical, Tuttlingen, Germany), a 20-mm deep pocket was created to obtain sufficient space in which to deposit the implant.

The implants consisted of $1.5 \mathrm{~mm}$ diameter sterile polyethylene tubing portions (BD ConnectaTM, Becton Dickinson Infusion Therapy AB). The polyethylene tubing was cut with a \#15 scalpel blade (Surgical Disposable Scalpel \# 15, Aesculap, Braun, Tuttlingen, Germany) into $5 \mathrm{~mm}$ long portions. No disinfection treatment was necessary for the tubes since they were sterile and packaged before use.

Four polyethylene tubes were implanted in each of the rats; three of them had been filled with the biomaterials under study, and the fourth was empty as a negative control of the histological reaction. The tubes were placed with a distance of at least $2 \mathrm{~cm}$ between them to avoid interference in the tissue response. A skin suture was made in each of the incisions with $2 / 0$ braided silk (Silkam ${ }^{\circledR}$, Braun, Tuttlingen, Germany). Four different groups were obtained: 1. Control. 2. MTA Angelus ${ }^{\circledR}$ (Angelus, Londrina, Brazil). 3. MTA Angelus ${ }^{\circledR}$ G3. 4. Theracal LC ${ }^{\circledR}$ (Bisco, Schaumburg, IL, USA).

\subsection{Sacrifice and Histological Analysis}

Once the period corresponding to each of the groups had ended, the animals were euthanized. To perform this, all the animals were administered a combination of a dissociative anesthetic, ketamine hydrochloride (Ketolar ${ }^{\circledR} 100 \mathrm{mg} / \mathrm{mL}$, (Pfizer Inc., New York, NY, USA)), at a dose of $75 \mathrm{mg} / \mathrm{kg}$ and an alpha-2 agonist, medetomidine (Domtor ${ }^{\circledR} 1 \mathrm{mg} / \mathrm{mL}$, Orion Corporation, Espoo, Finland) at doses of $0.5 \mathrm{mg} / \mathrm{kg}$ of weight intramuscularly (IM), prior to intracardiac (IC) administration of sodium pentobarbital (Dolethal ${ }^{\circledR} 200 \mathrm{mg} / \mathrm{mL}$, Vetoquinol SA, Lure, France). Three times the anesthetic dose is usually recommended. As confirmation and after the administration of drugs, all animals underwent a cervical dislocation. Verification of death was carried out by recognition of the animals [25].

To obtain the samples, the dorsal region of the rats was shaved in the groups in which the implantation of the biomaterials had been 30 and 45 days. In the 15-day group, it was not necessary. Subsequently, with a number 15 scalpel blade (Surgical Disposable Scalpel ${ }^{\circ}$ 15, Aesculap, Braun, Tuttlingen, Germany) and sterile scissors (Tekno 8365, Tekno Medical, Tuttlingen, Germany), the skin and subcutaneous connective tissue around the implant, including it, were resected. The surface area of the samples was approximately $2 \mathrm{~cm} \times 2 \mathrm{~cm}$. The samples were then placed in a 10\% buffered formaldehyde solution (Histogen 40, Serosep Ltd., Limerick, Ireland) until they were processed in the pathology laboratory. 
The evaluation of the histological preparations was carried out by two observers, by double blindness. In cases where there was a discrepancy, a third observer was consulted (Figure 1).

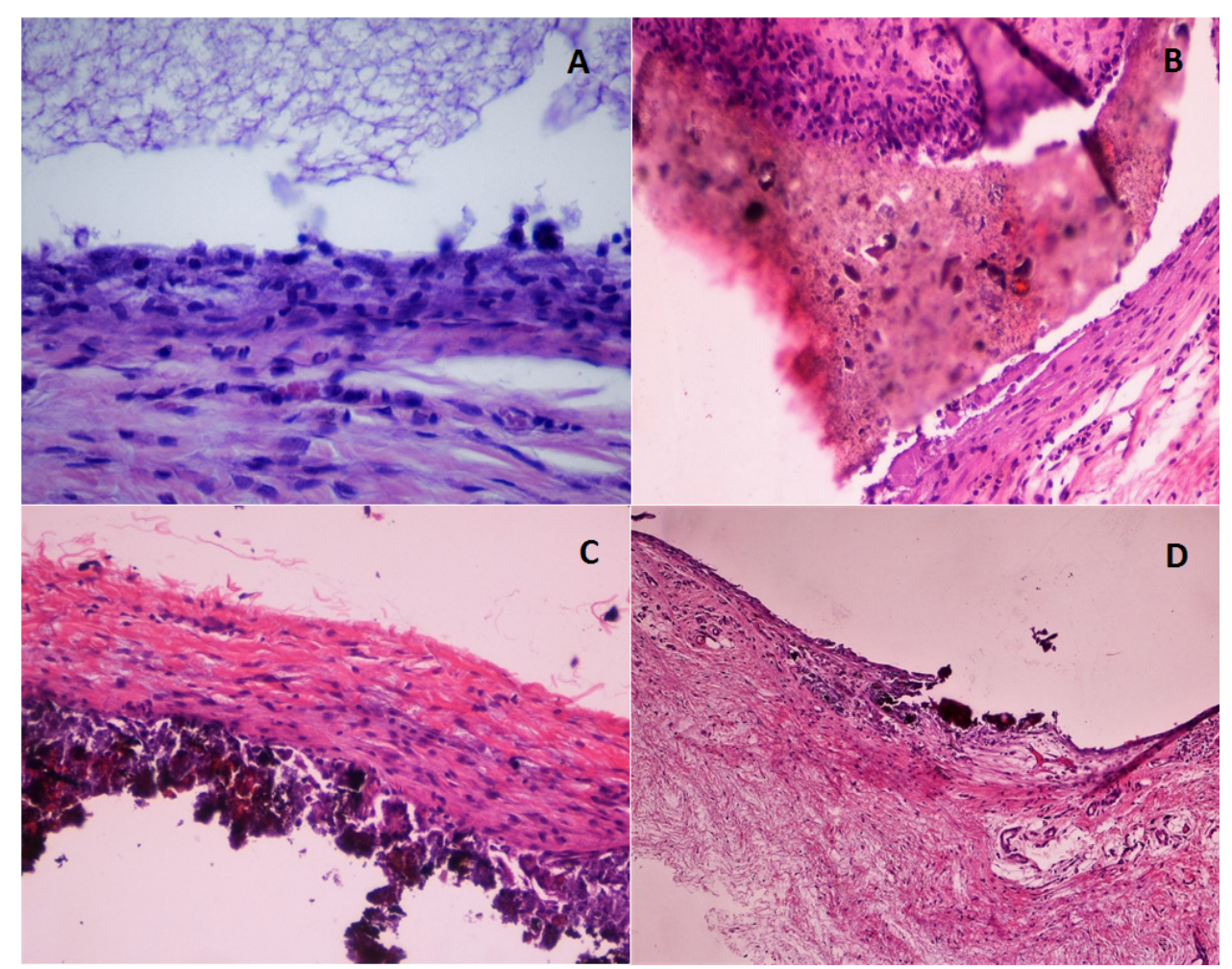

Figure 1. Hematoxylin-eosin stain. (A): Control. Fibrous capsule 30 days $(\times 400)$. (B): Theracal LC fibrous capsule 45 days $(\times 200)$. (C): MTA fibrous capsule surface calcification 45 days $(\times 200)$. (D): MTA-G3 fibrous capsule calcification 45 days $(\times 100)$.

To carry out the evaluation, the criteria of Taha et al. was used [26]. They are based on the criteria established by Parirokh et al. [27]. The criteria used by Taha et al. were slightly modified in our evaluation (Table 1).

Table 1. Criteria used to carry out the evaluation. They are based in Taha et al. but they were slightly modified in our evaluation.

\begin{tabular}{|c|c|c|c|c|c|c|c|}
\hline \multirow[b]{2}{*}{ Appearance } & \multirow[b]{2}{*}{ Category } & \multicolumn{6}{|c|}{ Grade } \\
\hline & & Value 0 & Value 1 & Value 2 & Value 3 & Value 4 & Value 5 \\
\hline \multirow{3}{*}{ Inflammation } & Kind & $\begin{array}{l}\text { Absence of } \\
\text { both types } \\
\text { (Acute and } \\
\text { chronic) }\end{array}$ & Chronicle & Sharp & Both types & & \\
\hline & $\begin{array}{c}\text { Intensity } \\
\text { (concentration of } \\
\text { inflammatory cells } \\
\text { per field } \times 40 \text { ) }\end{array}$ & $\begin{array}{l}\text { Inflammatory } \\
\text { cells are not } \\
\text { detected }\end{array}$ & $\begin{array}{l}\text { Less than } 25 \text { cells } \\
\text { (rare) }\end{array}$ & $\begin{array}{l}\text { Between } 25 \text { and } \\
50 \text { cells (mild) }\end{array}$ & $\begin{array}{c}\text { Between } 50 \text { and } \\
75 \text { cells } \\
\text { (moderate) }\end{array}$ & $\begin{array}{l}\text { More than } 75 \text { cells } \\
\text { (severe) }\end{array}$ & \\
\hline & Extension & $\begin{array}{l}\text { Inflammatory } \\
\text { cells are not } \\
\text { detected }\end{array}$ & $\begin{array}{l}\text { Inflammatory } \\
\text { cells are located } \\
\text { in the superficial } \\
\text { layer of the } \\
\text { capsule }\end{array}$ & $\begin{array}{l}\text { Inflammatory } \\
\text { cells located } \\
\text { within the limits } \\
\text { of the capsule }\end{array}$ & $\begin{array}{l}\text { Inflammatory } \\
\text { cells beyond the } \\
\text { capsule }\end{array}$ & $\begin{array}{l}\text { There is no } \\
\text { encapsulation. } \\
\text { Cells are limited to } \\
\text { the contact area }\end{array}$ & $\begin{array}{l}\text { There is no } \\
\text { encapsulation. } \\
\text { Inflammatory } \\
\text { cells spread } \\
\text { outside the } \\
\text { contact area }\end{array}$ \\
\hline $\begin{array}{l}\text { Fibroblastic } \\
\text { reaction }\end{array}$ & $\begin{array}{l}\text { Connective tissue } \\
\text { capsule }\end{array}$ & Absent & Immature form & $\begin{array}{c}\text { Mature, thin } \\
\text { form }(<150 \mu \mathrm{m})\end{array}$ & $\begin{array}{c}\text { Mature, coarse } \\
\text { form }(\geq 150 \mu \mathrm{m})\end{array}$ & & \\
\hline
\end{tabular}


Table 1. Cont.

\begin{tabular}{ccccccc}
\hline Appearance & Category & Value 0 & Value 1 & Value 2 & Value 3 & Value 4 \\
\hline $\begin{array}{c}\text { Foreign body } \\
\text { reaction }\end{array}$ & $\begin{array}{c}\text { Giant cells or foreign } \\
\text { body eosinophils }\end{array}$ & Absence & Presence & & & \\
\hline $\begin{array}{c}\text { Capillary } \\
\text { reaction }\end{array}$ & $\begin{array}{c}\text { Congestion in blood } \\
\text { vessels }\end{array}$ & Absence & Presence & & \\
\hline Tissue edema & Absence & $\begin{array}{c}\text { Limited areas of } \\
\text { tissue edema }\end{array}$ & $\begin{array}{c}\text { Widespread } \\
\text { areas of tissue } \\
\text { edema }\end{array}$ & \\
\hline Calcification & Absence & Presence & & \\
\hline Necrosis & Absence & Presence & & \\
\hline
\end{tabular}

\subsection{Statistical Analysis}

All the results were analyzed with the SPSS ${ }^{\circledR} 20.0$ (IBM, Armonk, NY, USA) for Windows statistical package. First, the results were described with percentages and then the potential association between the agent and the histological data were evaluated with the Mann-Whitney U test for dichotomic and quantitative variables and the Kruskal-Wallis test for politomic and quantitative variables.

\section{Results}

The intensity of the inflammatory reaction was evaluated with the number of inflammatory cells for the microscopic field of observation at $400 \times$ magnification. The density decreases with the duration of the implant. This decrease is statistically significant in tube implants with MTA $(p=0.004)$, Theracal LC $(p=0.001)$ and it is also significant with MTA-G3 $(p \leq 0.001)$ (Figure 2 and Table 2$)$.

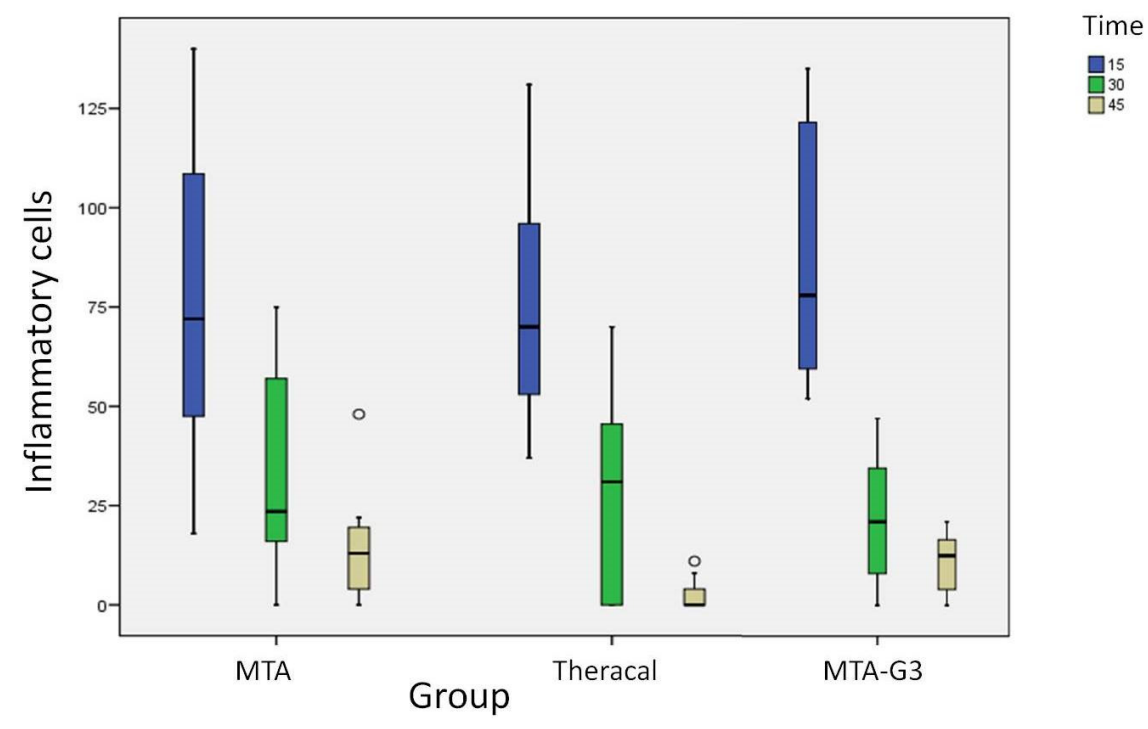

Figure 2. Number of inflammatory cells MTA, Theracal and MTA-G3. Differences between periods. The density decreases with the duration of the implant.

Table 2. Number of inflammatory cells MTA, Theracal and MTA-G3. Differences between periods.

\begin{tabular}{cccccc}
\hline PARAMETER & MATERIAL & DAY 15 & DAY 30 & DAY 45 & $p$ \\
\hline Number of & MTA & $72(74.5)$ & $23.5(47.5)$ & $13(18.75)$ & $0.004^{*}$ \\
inflammatory & MTA-G3 & $78(70.5)$ & $21(35.75)$ & $12.5(15.25)$ & $<0.001^{*}$ \\
cells Md(RIQ) & THER. & $70(58)$ & $31(46.75)$ & $0(6)$ & $0.001^{*}$ \\
\hline
\end{tabular}

${ }^{7}$, Kruskal-Wallis. 
If we compare the inflammatory reaction to the three materials according to periods, in the samples of 15 and 30 days, no differences were found between the three materials. However, in the 45-day samples, the differences are significant $(p=0.021)$. In this period, the median value of inflammatory cells with MTA turned out to be 13 cells, Md $(\mathrm{IQR})=13(18.75)$, in Theracal LC it was 0 cells, Md $(\mathrm{IQR})=0(6)$ and in the samples with MTA-G3 it was 12.5 cells (15.25) (Table 3 and Figure 3).

Table 3. Number of inflammatory cells MTA, Theracal and MTA-G3. Differences between materials according to periods.

\begin{tabular}{cccccc}
\hline PARAMETER & DAYS & MTA & THER. & MTA-G3 & $p$ \\
\hline Number of & 15 & $72(74.5)$ & $70(58)$ & $78(70.5)$ & $0.916^{*}$ \\
inflammatory & 30 & $23,5(47.5)$ & $31(46.75)$ & $21(35.75)$ & $0.711^{*}$ \\
cells Md(RIQ) & 45 & $13(18.75)$ & $0(6)$ & $12.5(15.25)$ & $0.021^{*}$ \\
\hline
\end{tabular}

*, Kruskal-Wallis.

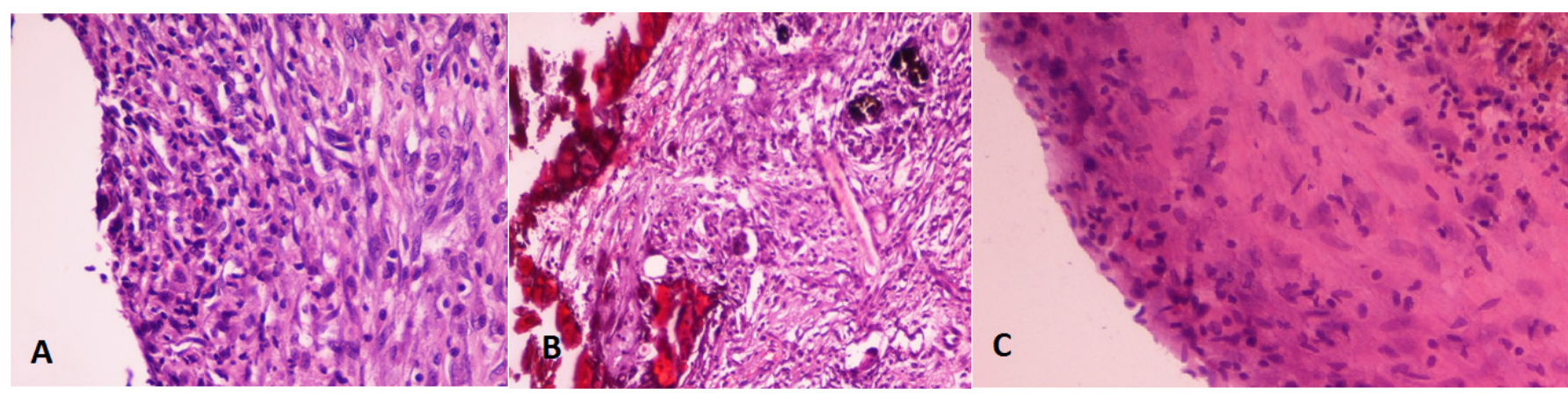

Figure 3. Type of cells predominant inflammatory response: lymphocytes, macrophages, and/or polymorphonuclear cells. Hematoxylin-eosin stain. (A): Theracal 15 days $(40 \times)$. (B): MTA-G3 15 days $(10 \times)$. (C): MTA 15 days $(20 \times)$.

Regarding qualitative variables studied to evaluate the tissue response, we observed that in the 15-day period, no significant differences were found in any of the parameters studied. The foreign body reaction and the appearance of calcifications had an identical frequency distribution (Table 4).

In the 30-day period, significant differences were found in the fibroblast reaction and in the appearance of dystrophic calcifications between MTA, MTA-G3 and Theracal (Table 5).

In the 45 -day period, we found that $75 \%$ of the samples from the Theracal LC implantation did not show signs of inflammation. In contrast, in the MTA and MTA-G3 samples, there was no inflammation in only two samples $(25 \%)$. However, the difference can be explained by chance $(p=0.132)$ (Table 6$)$.

Table 4. Qualitative variables MTA, MTA-G3 and Theracal, 15 days.

\begin{tabular}{|c|c|c|c|c|c|c|}
\hline PARAMETER & GRADE & MTA & THER. & MTA-G3 & Control & $p$ \\
\hline Type of inflammation & Absence & $0(0)$ & $0(0)$ & $0(0)$ & $0(0)$ & - \\
\hline$n(\%)$ & Chronic & $8(100)$ & $8(100)$ & $8(100)$ & $8(100)$ & \\
\hline \multirow{4}{*}{$\begin{array}{l}\text { Intensity } \\
n(\%)\end{array}$} & Limited & $1(12.5)$ & $0(0)$ & $0(0)$ & $0(0)$ & \multirow{4}{*}{0.551 * } \\
\hline & Mild & $1(12.5)$ & $2(25)$ & $0(0)$ & $0(0)$ & \\
\hline & Moderate & $3(37.5)$ & $4(50)$ & $4(50)$ & $5(62.5)$ & \\
\hline & Severe & $3(37.5)$ & $2(25)$ & $4(50)$ & $3(37.5)$ & \\
\hline $\begin{array}{l}\text { Number of inflammatory cells } \\
\text { Md(RIQ) }\end{array}$ & & $72(74.5)$ & $70(58)$ & $78(70.50)$ & $74.5(58.75)$ & $0.938^{* *}$ \\
\hline
\end{tabular}


Table 4. Cont.

\begin{tabular}{|c|c|c|c|c|c|c|}
\hline PARAMETER & GRADE & MTA & THER. & MTA-G3 & Control & $p$ \\
\hline \multirow{6}{*}{$\begin{array}{l}\text { Extension } \\
\quad n(\%)\end{array}$} & Not detected & $0(0)$ & $0(0)$ & $0(0)$ & $0(0)$ & \\
\hline & On capsule surface & $0(0)$ & $0(0)$ & $0(0)$ & $0(0)$ & \\
\hline & Inside the capsule & $5(62.5)$ & $2(25)$ & $0(0)$ & $3(37.5)$ & \\
\hline & Beyond the capsule & $3(37.5)$ & $3(37.5)$ & $6(75)$ & $5(62.5)$ & 0.058 * \\
\hline & In contact area & $0(0)$ & $3(37.5)$ & $2(25)$ & $0(0)$ & \\
\hline & Extended & $0(0)$ & $0(0)$ & $0(0)$ & $0(0)$ & \\
\hline \multirow{4}{*}{$\begin{array}{l}\text { Capsule } \\
n(\%)\end{array}$} & Absence & $0(0)$ & $1(12.5)$ & $2(25)$ & $0(0)$ & \\
\hline & Immature & $3(37.5)$ & $7(87.5)$ & $3(37.5)$ & $5(62.5)$ & 0.123 * \\
\hline & Fine & $3(37.5)$ & $0(0)$ & $1(12.5)$ & $3(37.5)$ & \\
\hline & Thick & $2(25)$ & $0(0)$ & $2(25)$ & $0(0)$ & \\
\hline $\begin{array}{c}\text { Capsule thickness } \\
\text { Md(RIQ) }\end{array}$ & & $128(188.5)$ & $0(0)$ & $241(58)$ & $83(87)$ & $0.212^{* *}$ \\
\hline \multirow{2}{*}{$\begin{array}{c}\text { Strange body } \\
n(\%)\end{array}$} & Yes & $4(50)$ & $4(50)$ & $5(62.5)$ & $2(25)$ & 0.497 * \\
\hline & No & $4(50)$ & $4(50)$ & $3(37.5)$ & $6(75)$ & \\
\hline \multirow{2}{*}{$\begin{array}{l}\text { Calcification } \\
n(\%)\end{array}$} & Yes & $5(62.5)$ & $5(62.5)$ & 7 (87.5) & $0(0)$ & 0.004 * \\
\hline & No & $3(37.5)$ & $3(37.5)$ & $1(12.5)$ & $8(100)$ & \\
\hline \multirow{2}{*}{$\begin{array}{c}\text { Congestion } \\
n(\%)\end{array}$} & Yes & $1(12.5)$ & $2(25)$ & $1(12.5)$ & $2(25)$ & $0.845^{*}$ \\
\hline & No & 7 (87.5) & $6(75)$ & 7 (87.5) & $6(75)$ & \\
\hline \multirow{2}{*}{$\begin{array}{l}\text { vEdema } \\
n(\%)\end{array}$} & Yes & $0(0)$ & $0(0)$ & $0(0)$ & $0(0)$ & - \\
\hline & No & $8(100)$ & $8(100)$ & $8(100)$ & $8(100)$ & \\
\hline \multirow{2}{*}{$\begin{array}{c}\text { Necrosis } \\
n(\%)\end{array}$} & Yes & $0(0)$ & $0(0)$ & $0(0)$ & $0(0)$ & - \\
\hline & No & $8(100)$ & $8(100)$ & $8(100)$ & $8(100)$ & \\
\hline
\end{tabular}

Table 5. Qualitative variables MTA, Theracal and MTA-G3, 30 days.

\begin{tabular}{|c|c|c|c|c|c|c|}
\hline PARAMETER & GRADE & MTA & THER. & MTA-G3 & Control & $p$ \\
\hline \multirow{2}{*}{$\begin{array}{l}\text { Type of inflammation } \\
\qquad n(\%)\end{array}$} & Absence & $1(12.5)$ & $3(37.5)$ & $2(25)$ & $2(25)$ & 0.612 \\
\hline & Chronic & 7 (87.5) & $5(62.5)$ & $6(75)$ & $6(75)$ & \\
\hline \multirow{4}{*}{$\begin{array}{l}\text { Intensity } \\
\quad n(\%)\end{array}$} & Limited & $1(12.5)$ & $3(37.5)$ & $2(25)$ & $2(25)$ & \\
\hline & Mild & $4(50)$ & $1(12.5)$ & $4(50)$ & $4(50)$ & 0.532 * \\
\hline & Moderate & $1(12.5)$ & $3(37.5)$ & $2(25)$ & $2(25)$ & \\
\hline & Severe & $2(25)$ & $1(12.5)$ & $0(0)$ & $0(0)$ & \\
\hline $\begin{array}{l}\text { Number of inflammatory cells } \\
\text { Md(RIQ) }\end{array}$ & & $23.5(47.5)$ & $31(46.75)$ & $21(35.75)$ & $38.50(58)$ & $0.620^{* *}$ \\
\hline \multirow{6}{*}{$\begin{array}{l}\text { Extension } \\
\quad n(\%)\end{array}$} & Not detected & $1(12.5)$ & $3(37.5)$ & $2(25)$ & $2(25)$ & \\
\hline & On capsule surface & $0(0)$ & $0(0)$ & $0(0)$ & $0(0)$ & \\
\hline & Inside the capsule & $5(62.5)$ & $1(12.5)$ & $6(75)$ & $3(37.5)$ & \\
\hline & Beyond the capsule & $1(12.5)$ & $4(50)$ & $0(0)$ & $3(37.5)$ & $0.166^{*}$ \\
\hline & In contact area & $1(12.5)$ & $0(0)$ & $0(0)$ & $0(0)$ & \\
\hline & Extended & $0(0)$ & $0(0)$ & $0(0)$ & $0(0)$ & \\
\hline \multirow{4}{*}{$\begin{array}{l}\text { Capsule } \\
n(\%)\end{array}$} & Absence & $2(25)$ & $0(0)$ & $2(25)$ & $0(0)$ & \\
\hline & Immature & $2(25)$ & $0(0)$ & $0(0)$ & $0(0)$ & $0.016^{*}$ \\
\hline & Fine & $0(0)$ & 7 (87.5) & $4(50)$ & $7(87.5)$ & \\
\hline & Thick & $4(50)$ & $1(12.5)$ & $2(25)$ & $1(12.5)$ & \\
\hline $\begin{array}{l}\text { Capsule thickness } \\
\text { Md(RIQ) }\end{array}$ & & $187(32.25)$ & $93(40.75)$ & $120.5(162.5)$ & $68(81.5)$ & $0.047^{* *}$ \\
\hline
\end{tabular}


Table 5. Cont.

\begin{tabular}{|c|c|c|c|c|c|c|}
\hline PARAMETER & GRADE & MTA & THER. & MTA-G3 & Control & $p$ \\
\hline \multirow{2}{*}{$\begin{array}{c}\text { Strange body } \\
n(\%)\end{array}$} & Yes & $0(0)$ & $1(12.5)$ & $1(12.5)$ & $1(12.5)$ & $0.545^{*}$ \\
\hline & No & $8(100)$ & 7 (87.5) & 7 (87.5) & 7 (87.5) & \\
\hline \multirow{2}{*}{$\begin{array}{c}\text { Calcification } \\
n(\%)\end{array}$} & Yes & $8(100)$ & $2(37.5)$ & $2(37.5)$ & $0(0)$ & $<0.001$ * \\
\hline & No & $0(0)$ & $6(75)$ & $6(75)$ & $8(100)$ & \\
\hline \multirow{2}{*}{$\begin{array}{c}\text { Congestion } \\
n(\%)\end{array}$} & Yes & $0(0)$ & $0(0)$ & $0(0)$ & $0(0)$ & - \\
\hline & No & $8(100)$ & $8(100)$ & $8(100)$ & $8(100)$ & \\
\hline \multirow{2}{*}{$\begin{array}{c}\text { Edema } \\
n(\%)\end{array}$} & Yes & $0(0)$ & $0(0)$ & $0(0)$ & $0(0)$ & - \\
\hline & No & $8(100)$ & $8(100)$ & $8(100)$ & $8(100)$ & \\
\hline \multirow{2}{*}{$\begin{array}{c}\text { Necrosis } \\
n(\%)\end{array}$} & Yes & $0(0)$ & $0(0)$ & $0(0)$ & $0(0)$ & - \\
\hline & No & $8(100)$ & $8(100)$ & $8(100)$ & $8(100)$ & \\
\hline
\end{tabular}

${ }^{*}, \chi^{2}$ Pearson, ${ }^{* *}$, Kruskal-Wallis.

Table 6. Qualitative variables MTA, Theracal and MTA-G3, 45 days.

\begin{tabular}{|c|c|c|c|c|c|c|}
\hline PARAMETER & GRADE & MTA & THER. & MTA-G3 & Control & $p$ \\
\hline \multirow{2}{*}{$\begin{array}{l}\text { Type of inflammation } \\
\qquad n(\%)\end{array}$} & Absence & $2(25)$ & $6(75)$ & $2(25)$ & $3(37.5)$ & 0.188 * \\
\hline & Chronic & $6(75)$ & $2(25)$ & $6(75)$ & $5(62.5)$ & \\
\hline \multirow{5}{*}{$\begin{array}{l}\text { Intensity } \\
n(\%)\end{array}$} & Absence cells & $2(25)$ & $6(75)$ & $2(12.5)$ & $3(37.5)$ & \\
\hline & Limited & $5(62.5)$ & $2(25)$ & $6(75)$ & $4(50)$ & \\
\hline & Mild & $1(12.5)$ & $0(0)$ & $0(0)$ & $0(0)$ & 0.251 * \\
\hline & Moderate & $0(0)$ & $0(0)$ & $0(0)$ & $1(12.5)$ & \\
\hline & Severe & $0(0)$ & $0(0)$ & $0(0)$ & $0(0)$ & \\
\hline $\begin{array}{l}\text { Number of inflammatory cells } \\
\text { Md(RIQ) }\end{array}$ & & $13(18.75)$ & $0(6)$ & $12.5(15.25)$ & $12(19.5)$ & $0.081 * *$ \\
\hline \multirow{6}{*}{$\begin{array}{l}\text { Extension } \\
\quad n(\%)\end{array}$} & Not detected & $2(25)$ & $6(75)$ & $1(12.5)$ & $3(37.5)$ & \\
\hline & On capsule surface & $0(0)$ & $0(0)$ & $1(12.5)$ & $0(0)$ & \\
\hline & Inside the capsule & $4(50)$ & $2(25)$ & $1(12.5)$ & $4(50)$ & \\
\hline & Beyond the capsule & $1(12.5)$ & $0(0)$ & $3(37.5)$ & $0(0)$ & 0.125 * \\
\hline & In contact area & $1(12.5)$ & $0(0)$ & $1(12.5)$ & $1(12.5)$ & \\
\hline & Extended & $0(0)$ & $0(0)$ & $0(0)$ & $0(0)$ & \\
\hline \multirow{4}{*}{$\begin{array}{l}\text { Capsule } \\
n(\%)\end{array}$} & Absence & $2(25)$ & $0(0)$ & & $1(12.5)$ & \\
\hline & Immature & $0(0)$ & $0(0)$ & & $0(0)$ & 0.274 * \\
\hline & Fine & $4(50)$ & $8(100)$ & $2(25)$ & $7(87.5)$ & \\
\hline & Thick & $2(25)$ & $0(0)$ & $0(0)$ & $0(0)$ & \\
\hline $\begin{array}{l}\text { Capsule thickness } \\
\text { Md(RIQ) }\end{array}$ & & $101.5(92.25)$ & $93(65.25)$ & $82(58.25)$ & $43(18)$ & $0.003^{* *}$ \\
\hline Strange body & Yes & $0(0)$ & $0(0)$ & $0(0)$ & $1(12.5)$ & $0.396^{*}$ \\
\hline$n(\%)$ & No & $8(100)$ & $8(100)$ & $8(100)$ & 7 (87.5) & \\
\hline Calcification & Yes & $5(62.5)$ & $2(37.5)$ & $2(37.5)$ & $0(0)$ & 0.048 * \\
\hline$n(\%)$ & No & $3(37.5)$ & $6(75)$ & $6(75)$ & $8(100)$ & \\
\hline Congestion & Yes & $0(0)$ & $0(0)$ & $0(0)$ & $0(0)$ & - \\
\hline$n(\%)$ & No & $8(100)$ & $8(100)$ & $8(100)$ & $8(100)$ & \\
\hline Edema & Yes & $0(0)$ & $0(0)$ & $0(0)$ & $0(0)$ & - \\
\hline$n(\%)$ & No & $8(100)$ & $8(100)$ & $8(100)$ & $8(100)$ & \\
\hline Necrosis & Yes & $0(0)$ & $0(0)$ & $0(0)$ & $0(0)$ & - \\
\hline$n(\%)$ & No & $8(100)$ & $8(100)$ & $8(100)$ & $8(100)$ & \\
\hline
\end{tabular}


On the other hand, a comparative study of the formation of calcifications was carried out, without taking into account the implantation period. Dystrophic calcification occurred in $75 \%$ of the samples with MTA, $37.5 \%$ in those with Theracal LC implantation and $45.8 \%$ in the MTA-G3 samples, finding differences between MTA and MTA-G3/Theracal (Table 7 and Figure 4).

Table 7. Presence of MTA, Theracal and MTA-G3 calcifications.

\begin{tabular}{ccccc}
\hline PARAMETER & GRADE & MTA & THER. & MTA-G3 \\
\hline Calcification & Yes & $18(75)$ & $9(37.5)$ & $11(45.8)$ \\
$n(\%)$ & No & $6(25)$ & $15(62.5)$ & $13(54.2)$ \\
\hline
\end{tabular}

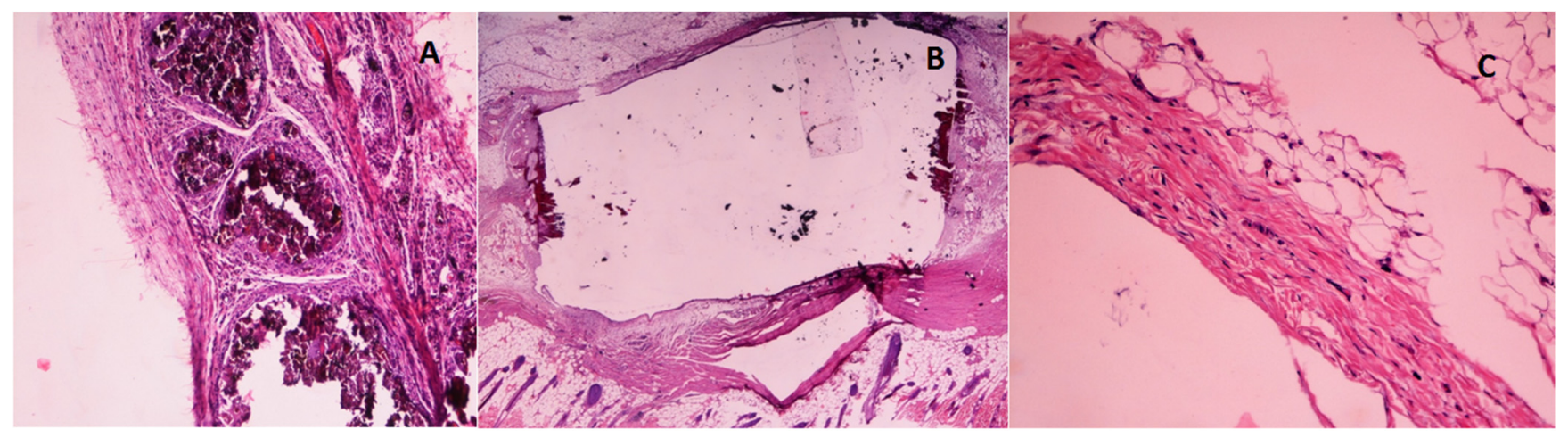

Figure 4. Hematoxylin-eosin stain. (A): Dystrophic calcification in the area of contact with MTA 30 days (200×). (B): Calcification on the open ends of the MTA-G3 polyethylene tube 30 days $(40 \times)$. (C): $136 \mu \mathrm{m}$ thick fibrous capsule Theracal 45 days $(200 \times)$.

Regarding the thickness of the fibrous capsule, no statistically significant differences were found in MTA of 15, 30 and 45 days $(p=0.08)$, nor in MTA-G3 ( $p=0.068)$. With respect to Theracal LC, none of the 15-day histological sections presented mature capsules, and no significant differences were found in the thickness of the capsules in the 30-day samples compared to the 45 -day samples $(p=0.834)$ (Figure 5 and Table 8$)$. If we compare the median value of the measurement in microns of the three materials with each other, by periods, we obtain that there is a significant difference between MTA/MTA-G3 and Theracal LC in the 30-day samples $(p=0.041)$. The capsule formed against MTA and MTA-G3 was found to be $94 \mu \mathrm{m}$ thicker (Table 9).

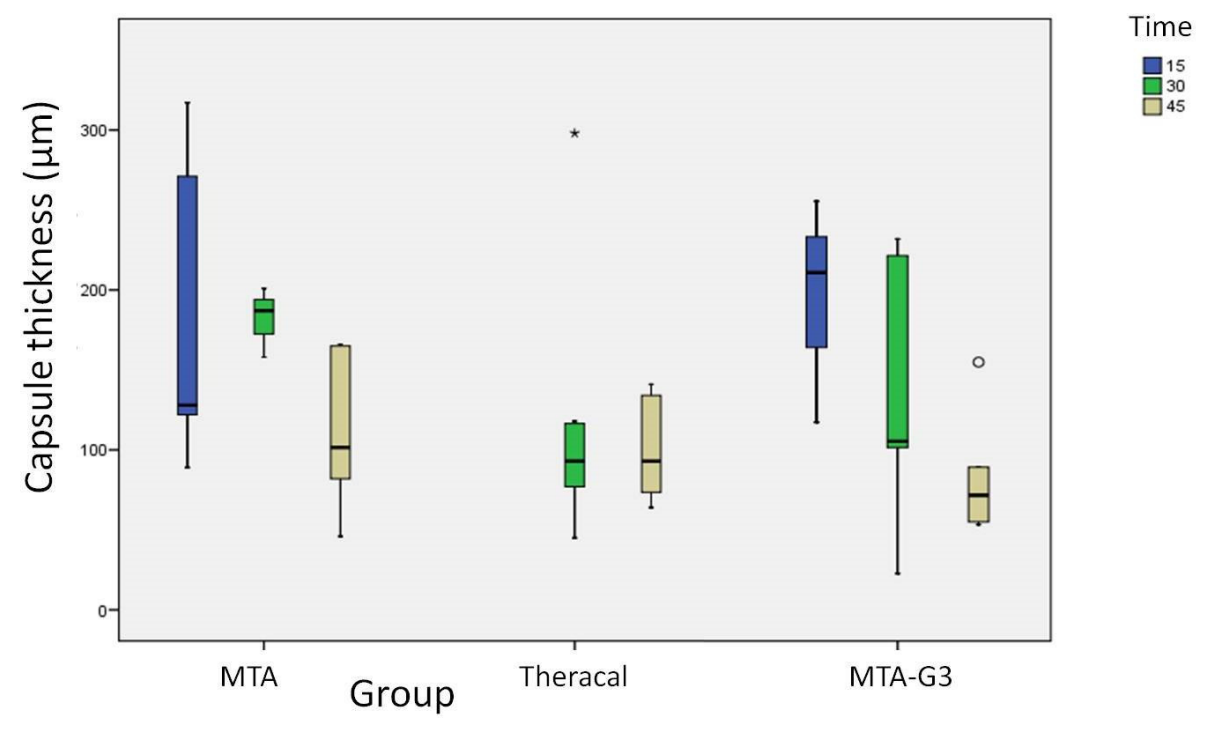

Figure 5. MTA, Theracal and MTA-G3 fibrous capsule thickness. Differences between periods. 
Table 8. MTA, Theracal and MTA-G3 fibrous capsule thickness. Differences between periods.

\begin{tabular}{cccccc}
\hline PARAMETER & MATERIAL & DAY 15 & DAY 30 & DAY 45 & $p$ \\
\hline Thickness $(\mu \mathrm{m})$ & MTA & $128(188.5)$ & $187(32.25)$ & $101.5(92.25)$ & $0.08^{*}$ \\
Md(RIQ) & THER. & & $93(40.75)$ & $93(65.25)$ & $0.834^{* *}$ \\
& MTA-G3 & $241(158)$ & $120.5(162.5)$ & $82(58.25)$ & $0.068^{*}$ \\
\hline
\end{tabular}

${ }^{*} \chi^{2}$ Pearson, ${ }^{* *}$, Kruskal-Wallis.

Table 9. MTA, Theracal and MTA-G3 fibrous capsule thickness. Differences between materials according to period.

\begin{tabular}{ccccc}
\hline PARAMETER & DAYS & MTA & THER. & MTA-G3 \\
\hline Thickness $(\mu \mathrm{m})$ & 15 & $128(188.5)$ & & $241(158)$ \\
Md(RIQ) & 30 & $187(32.25)$ & $93(40.75)$ & $120.5(162.5)$ \\
& 45 & $101.5(92.25)$ & $93(65.25)$ & $82(58.25)$ \\
\hline
\end{tabular}

\section{Discussion}

The tissue response with MTA was characterized by a chronic, moderate inflammation, which with the passage of time lost intensity until it practically disappeared after 45 days of contact with the material. The initial degree of inflammation can be a response to several factors such as high $\mathrm{pH}$, the temperature generated during setting, and the generation of cytokines, such as interleukin-1 and interleukin-6 [28]. The connective tissue was arranged in the form of collagen fibbers that formed fibrous capsules around the tube and its open ends that had direct contact with the material. The most significant histological changes were characterized by the formation of dystrophic calcifications. These were already evident in $62.5 \%$ of the samples on day 15 , appearing in all the samples in the longest periods. Bramante et al. [23] differ from our results in that at 15 days, they only observed a few inflammatory cells and it made no reference to calcifications in any of the groups. Holland et al. [7] describe the existence of birefringent formations in polarized light, possibly calcite crystals. These formations are consistent with the calcifications in the tissue found in our study. Conversely, the proportion of samples with dystrophic calcifications in our study is much higher than that of Taha et al. [26]; this could be due to the use of a different variety of MTA (Angelus vs. ProRoot MTA). Angelus MTA composition is 5\% more Portland cement than ProRoot MTA. In addition, the shape and size of the particles is less homogeneous [29]. Shahi et al. [5] describe the presence of a chronic inflammatory infiltrate, collagen fibbers and fibrosis at 21 days. Parirokh et al. [30] describe calcium precipitations in $33 \%$ of the samples with GMTA and $22 \%$ of the samples with WMTA. In our study, we also found the presence of calcifications in much higher percentages. Calcifications were seen in $75 \%$ of the samples with MTA and in $54 \%$ of the samples with MTA-G3.

Martínez Lalis et al. [22] report a chronic inflammatory infiltrate and the formation of organized fibrous tissue whose results do not contradict ours. Yaltirik et al. [6] agree with our results, since in the 15-day samples they describe the presence of dystrophic calcifications and a moderate infiltration of inflammatory cells, in which macrophages and multinucleated giant cells can be seen; at 30 days, they observe calcifications and the formation of fine fibrous capsules, together with a decrease in inflammatory cells.

The formation of calcium structures in the subcutaneous connective tissue is a sign of osteoinductive activity of the evaluated material [31], in this case the MTA. Calcite crystals are formed due to the reaction of calcium from calcium hydroxide with carbon dioxide from connective tissue. Calcium hydroxide originates from calcium phosphate and calcium oxide, which releases MTA [5].

The biocompatibility of MTA is also related to its property to release calcium ions, since it causes an elevation in the $\mathrm{pH}$ of the medium and does not allow bacterial growth [32].

We have not found any work in which the implantation in the subcutaneous connective tissue of MTA was carried out with the G3 glass. López-Píriz et al. coated with G3 
implants used in Beagle dogs, demonstrating the biocidal nature of glass, and its ability to prevent bone resorption [20], but its effectiveness in reducing response in tissue has not been demonstrated.

The tissue response to MTA-G3 did not differ from MTA in any of the parameters studied and the addition of glass did not improve, nor did it worsen the tissue response to MTA. Differences were only found in the 30-day group, where MTA presented more calcifications than MTA-G3. It is possible that $25 \%$ less cement than the mix has in its composition is the main cause. Surely if the comparison between MTA and G3 were made at $100 \%$, the difference would be much more important.

The use of Theracal did not elicit any macroscopically visible lesions. At 15 days, the samples presented a chronic inflammation of moderate or severe intensity, and at 45 days it was scarce and practically disappeared in almost all the samples. In the statistical study, no statistically significant differences were found.

The difference between median values was only 13 inflammatory cells. Considering that no significant differences were found between type and intensity of inflammation between MTA and negative controls, we have to subtract significance from this small difference between MTA and Theracal LC.

Some authors conducted in vitro cytotoxicity studies and described greater cell viability in experiments with MTA than in those using Theracal LC; we believe that it must be considered that in the living model, the cellular response, inflammatory phenomena and reparative actions may be determining factors of the final result and the conclusions of the study [33].

Regarding the fibroblastic reaction, the connective tissue was organized into collagen fibbers and fibroblasts that were forming palisades. At 15 days, none of the fibrous capsules were still mature, but at 30 days, all of the samples had a capsule formed around the Theracal LC and around the polyethylene tubes. The thickness of the capsules that were formed against Theracal LC was $94 \mu \mathrm{m}$ lower (difference between medians) than the capsules formed with MTA. At 45 days, the thickness of the capsules formed against Theracal was practically the same. Martínez-Lalis et al. also measured the thickness of the fibrous capsule formed around the implanted material [22]. The formation of fibrous connective tissue around the implanted material indicates that it has been well tolerated by the surrounding tissues [6]. Parirokh et al. stated that the formation of a fibrous capsule and the progressive decrease in its thickness over time is one of the signs of biocompatibility [30].

Another of the findings found in the Theracal samples were calcifications. Observing that the proportion of samples with calcifications was higher at 15 days $(62.5 \%)$ than at 45 days (25\%), the samples were compared regardless of the period. The samples with MTA ${ }^{\circledR}$ and MTA/G3 presented two times more dystrophic calcifications than with Theracal LC ${ }^{\circledR}$. If we take into account that $\mathrm{MTA}^{\circledR}$ has $35 \%$ more Portland cement in its composition than Theracal $\mathrm{LC}^{\circledR}$, the content of calcium salts is much higher in MTA. The difference in calcium ions in the composition of both materials could explain the greater formation of calcifications in the samples with MTA. Torneck et al. stated that calcium ions would activate ATP, which would play an important role in the mineralization process in tissues [34].

Gandolfi et al. observed, however, that Theracal $\mathrm{LC}^{\circledR}$ released more calcium ions during the first few days than ProRoot $\mathrm{MTA}^{\circledR}$ in an experimental in vitro study [11], demonstrating that Theracal $\mathrm{LC}^{\circledR}$ was capable of releasing calcium and hydroxyl ions for at least 28 days.

One of the possible advantages of using Theracal as a potential root-end filling would be the combination with moisture necessary for setting, since in these procedures it is very complex to achieve a lack of total humidity and, in addition, polymerization would allow us to check the plug in situ. The fact that it is light-cured is not a problem during root-end surgery, as has been demonstrated in the literature [35]. 
Hinata et al. evaluated the abilities of TheraCal LC to produce apatite-like precipitates after being subcutaneously implanted into rats at 7, 14 and 28 days post-implantation through scanning electron microscopy (SEM-EPMA). This study concluded that the thickness of the Ca-and P-rich region was thicker in MTA versus Theracal [36]. The deposition of mineralized materials (dystrophic mineralization) adjacent to materials has been considered to be a crucial event during mineralized tissue repair [37]; the present study has analyzed samples in 15, 30 and 45 days and the presence of $\mathrm{Ca}$ and $\mathrm{P}$ ions have not been evaluated, but calcifications were similar finding the presence of a greater number of calcifications in MTA versus Theracal. Fibrous capsule thickness increased over time, which could confirm that the release of Theracal is sustained over time.

One of the limitations of the study is the subjective nature of the parameters evaluated in the observation of the histological preparations. Although the established criteria are objective, the data recorded by pathologists may vary depending on the microscopic field observed or the histological section studied. Furthermore, the results cannot be extrapolated to man, based solely on the data obtained in the experimental animals, but the implantation of the experimental materials in the subcutaneous connective tissue of the rat is considered by many authors as a valid procedure for the study of its biological properties [38,39].

\section{Conclusions}

Theracal LC as well as the MTA Angelus were well tolerated when implanted in the rat's subcutaneous connective tissue.

Theracal LC and MTA with the bioactive glass G3, caused an inflammatory reaction, which at 15 days was chronic and decreased in intensity, until almost disappearing after 45 days of contact. No edema or necrosis were observed. A fibrous capsule was formed, which once mature, was decreasing in thickness, around the polyethylene tubes and the biomaterials evaluated.

Angelus MTA induces the formation of dystrophic calcifications twice as much as Theracal LC. The addition of bioglass G3 in 25\% did not affect the greater or lesser occurrence of calcifications. No problem was found histologically for the direct contact use of Theracal LC, and the mixing of MTA with 25\% bioactive G3 glass, with the connective tissue.

Supplementary Materials: The following are available online at https:/ /www.mdpi.com/article/10 .3390/jcm10122536/s1, Checklist S1: ARRIVE guidelines checklist.

Author Contributions: Conceptualization, J.C.-U. and J.M.-Á., design, J.M.-Á.; data acquisition, J.C.-U., P.A.-S.; formal analysis, J.C.-U., C.G.-O., C.R.-R. and J.M.-Á.; performed all statistical analyses, C.G.-O. and C.R.-R.; drafted, J.M.-Á.; review and editing, J.C.-U. and J.M.-Á. All authors have read and agreed to the published version of the manuscript.

Funding: This research received no external funding.

Institutional Review Board Statement: The present research project has been approved by the Ethical Committee for Research of University Alfonso X el Sabio, by the Ethical Committee of the Animal Research Service of the Hospital Militar Gómez Ulla of Madrid (Ref. ES280810000233) and also by the Environment, Local Administration and Territorial Organization Office of Madrid Autonomy (order number PROEX 065/17).

Informed Consent Statement: Not applicable.

Data Availability Statement: The datasets used and/or analyzed during the current study are available from the corresponding author on reasonable request.

Acknowledgments: Authors would like to thank Roberto López-Piriz, Diego Vargas Cocinero, Miguel Angel Sanz García and personal of Central Defense Hospital "Gomez Ulla" for their assistance in this study.

Conflicts of Interest: The authors declare no conflict of interest. 


\section{References}

1. Ozbas, H.; Yaltirik, M.; Bilgic, B.; Issever, H. Reactions of connective tissue to compomers, composite and amalgam root-end filling materials. Int. Endod. J. 2003, 36, 281-287. [CrossRef]

2. Mohammadi, Z.; Modaresi, J.; Yazdizadeh, M. Evaluation of the antifungal effects of mineral trioxide aggregate materials. Aust. Endod. J. 2006, 32, 120-122. [CrossRef]

3. Torabinejad, M.; Ford, T.R.P.; McKendry, D.J.; Abedi, H.R.; Miller, D.A.; Kariyawasam, S.P. Histologic assessment of mineral trioxide aggregate as a root-end filling in monkeys. J. Endod. 1997, 23, 225-228. [CrossRef]

4. Torabinejad, M.; Ford, T.R.P.; Abedi, H.R.; Kariyawasam, S.P.; Tang, H.-M. Tissue reaction to implanted root-end filling materials in the tibia and mandible of guinea pigs. J. Endod. 1998, 24, 468-471. [CrossRef]

5. Shahi, S.; Rahimi, S.; Lotfi, M.; Yavari, H.; Gaderian, A. A Comparative Study of the Biocompatibility of Three Root-end Filling Materials in Rat Connective Tissue. J. Endod. 2006, 32, 776-780. [CrossRef] [PubMed]

6. Yaltirik, M.; Ozbas, H.; Bilgic, B.; Issever, H. Reactions of Connective Tissue to Mineral Trioxide Aggregate and Amalgam. J. Endod. 2004, 30, 95-99. [CrossRef] [PubMed]

7. Holland, R.; de Souza, V.; Nery, M.J.; Filho, J.A.O.; Bernabé, P.F.; Dezan, E. Reaction of rat connective tissue to implanted dentin tubes filled with mineral trioxide aggregate or calcium hydroxide. J. Endod. 1999, 25, 161-166. [CrossRef]

8. Abedi, H.R.; Ingle, J. Mineral trioxide aggregate: A review of a new cement. J. Calif. Dent. Assoc. 1995, 23, 39.

9. Economides, N.; Pantelidou, O.; Kokkas, A.; Tziafas, D. Short-term periradicular tissue response to mineral trioxide aggregate (MTA) as root-end filling material. Int. Endod. J. 2003, 36, 44-48. [CrossRef] [PubMed]

10. Thomson, T.S.; Berry, J.; Somerman, M.J.; Kirkwood, K.L. Cementoblasts Maintain Expression of Osteocalcin in the Presence of Mineral Trioxide Aggregate. J. Endod. 2003, 29, 407-412. [CrossRef]

11. Gandolfi, M.G.; Siboni, F.; Prati, C. Chemical-physical properties of TheraCal, a novel light-curable MTA-like material for pulp capping. Int. Endod. J. 2012, 45, 571-579. [CrossRef] [PubMed]

12. Suh, B.; Cannon, M.; Martín, D. Polymerizable Dental Pulp Healing, Capping and Lining Material and Method for Use. U.S Patent Application No. 12/034,093, 25 December 2008.

13. Lee, B.N.; Lee, B.G.; Chang, H.S.; Hwang, Y.C.; Hwang, I.N.; Oh, W.M. Effects of a novel light-curable material on odontoblastic differentiation of human dental pulp cells. Int. Endod. J. 2017, 50, 464-471. [CrossRef] [PubMed]

14. Lee, H.; Shin, Y.; Kim, S.O.; Lee, H.-S.; Choi, H.-J.; Song, J.S. Comparative Study of Pulpal Responses to Pulpotomy with ProRoot MTA, RetroMTA, and TheraCal in Dogs' Teeth. J. Endod. 2015, 41, 1317-1324. [CrossRef]

15. Camilleri, J.; Laurent, P.; About, I. Hydration of biodentine, theracal LC, and a prototype tricalcium silicate-based dentin replacement material after pulp capping in entire tooth cultures. J. Endod. 2014, 40, 1846-1854. [CrossRef]

16. Camilleri, J. Hydration characteristics of Biodentine and Theracal used as pulp capping materials. Dent. Mater. 2014, 30, 709-715. [CrossRef]

17. Al-Hyali, N.A. Comparison among Pulp Capping Materials in Calcium Ion Release, pH Change, Solubility and Water Sorption: An In Vitro Study. J. Baghdad Coll. Dent. 2017, 29, 9-16. [CrossRef]

18. Demirkaya, K.; Can Demirdöğen, B.; Öncel Torun, Z.; Erdem, O.; Çetinkaya, S.; Akay, C. In vivo evaluation of the effects of hydraulic calcium silicate dental cements on plasma and liver aluminium levels in rats. Eur. J. Oral Sci. 2016, $124,75-81$. [CrossRef] [PubMed]

19. Cannon, M.; Gerodias, N.; Vieira, A.; Percinoto, C.; Jurado, R. Primate Pulpal Healing after Exposure and TheraCal Application. J. Clin. Pediatr. Dent. 2014, 38, 333-337. [CrossRef] [PubMed]

20. López-Píriz, R.; Solá-Linares, E.; Rodriguez-Portugal, M.; Malpica, B.; Díaz-Güemes, I.; Enciso, S.; Esteban-Tejeda, L.; Cabal, B.; Granizo, J.J.; Moya, J.S.; et al. Evaluation in a dog model of three antimicrobial glassy coatings: Prevention of bone loss around implants and microbial assessments. PLoS ONE 2015, 10, e0140374. [CrossRef]

21. Moya, J.S.; Martínez, A.; López-Píriz, R.; Guitián, F.; Díaz, L.A.; Esteban-Tejeda, L.; Cabal, B.; Sket, F.; Fernández-García, E.; Tomsia, A.P.; et al. Histological response of soda-lime glass-ceramic bactericidal rods implanted in the jaws of beagle dogs. Sci. Rep. 2016, 6, 31478. [CrossRef]

22. Martínez Lalis, R.; Esaín, M.L.; Kokubu, G.A.; Willis, J.; Chaves, C.; Grana, D.R. Rat subcutaneous tissue response to modified Portland cement, a new mineral trioxide aggregate. Braz. Dent. J. 2009, 20, 112-117. [CrossRef]

23. Bramante, C.; Kato, M.M.; Assis, G.; Duarte, M.A.H.; Bernardineli, N.; De Moraes, I.G.; Garcia, R.B.; Ordinola-Zapata, R.; Bramante, A.S. Biocompatibility and setting time of CPM-MTA and white Portland cement clinker with or without calcium sulfate. J. Appl. Oral Sci. 2013, 21, 32-36. [CrossRef]

24. Sumer, M.; Muglali, M.; Bodrumlu, E.; Guvenc, T. Reactions of Connective Tissue to Amalgam, Intermediate Restorative Material, Mineral Trioxide Aggregate, and Mineral Trioxide Aggregate Mixed With Chlorhexidine. J. Endod. 2006, 32, 1094-1096. [CrossRef]

25. Close, B.; Banister, K.; Baumans, V.; Bernoth, E.M.; Bromage, N.; Erhardt, W.; Bunyan, J.; Flecknell, P.; Gregory, N.; Hackbarth, H.; et al. Recommendations for euthanasia of experimental animals: Part 2. Lab. Anim. 1997, 31, 1-32. [CrossRef] [PubMed]

26. Taha, N.A.; Safadi, R.A.; Alwedaie, M.S. Biocompatibility Evaluation of EndoSequence Root Repair Paste in the Connective Tissue of Rats. J. Endod. 2016, 42, 1523-1528. [CrossRef]

27. Parirokh, M.; Torabinejad, M. Mineral Trioxide Aggregate: A Comprehensive Literature Review-Part III: Clinical Applications, Drawbacks, and Mechanism of Action. J. Endod. 2010, 36, 400-413. [CrossRef] [PubMed] 
28. Koh, E.; Torabinejad, M.; Pitt Ford, T.; Brady, K.; McDonald, F. Mineral trioxide aggregate stimulates a biological response in human osteoblasts. J. Biomed. Mater. Res. 1997, 37, 432-439. [CrossRef]

29. Oliveira, M.; Xavier, C.; Demarco, F.; Pinheiro, A.; Costa, A.; Pozza, D. Comparative chemical study of MTA and Portland cements. Braz. Dent. J. 2007, 18, 3-7. [CrossRef] [PubMed]

30. Parirokh, M.; Mirsoltani, B.; Raoof, M.; Tabrizchi, H.; Haghdoost, A. Comparative study of subcutaneous tissue responses to a novel root-end filling material and white and grey mineral trioxide aggregate. Int. Endod. J. 2010, 44, 283-289. [CrossRef]

31. Moretton, T.R.; Brown, C.E.; Legan, J.J.; Kafrawy, A.H. Tissue reactions after subcutaneous and intraosseous implantation of mineral trioxide aggregate and ethoxybenzoic acid cement. J. Biomed. Mater. Res. 2000, 52, 528-533. [CrossRef]

32. Aguilar, F.G.; Garcia, L.F.R.; Pires-de-Souza, F.C.P. Biocompatibility of New Calcium Aluminate Cement (EndoBinder). J. Endod. 2012, 38, 367-371. [CrossRef]

33. Poggio, C.; Arciola, C.R.; Beltrami, R.; Monaco, A.; Dagna, A.; Lombardini, M.; Visai, L. Cytocompatibility and Antibacterial Properties of Capping Materials. Sci. World J. 2014, 2014, 1-10. [CrossRef]

34. Torneck, C.; Moe, H.; Howley, T. The effect of calcium hydroxide on porcine pulp fibroblasts in vitro. J. Endod. 1983, 9, 131-136. [CrossRef]

35. Abedi-Amin, A.; Luzi, A.; Giovarruscio, M.; Paolone, G.; Darvizeh, A.; Agullo, V.V.; Sauro, S. Innovative root-end filling materials based on calcium-silicates and calcium-phosphates. J. Mater. Sci. Mater. Med. 2017, 28, 31. [CrossRef] [PubMed]

36. Hinata, G.; Yoshiba, K.; Han, L.; Edanami, N.; Yoshiba, N.; Okiji, T. Bioactivity and biomineralization ability of calcium silicate-based pulp-capping materials after subcutaneous implantation. Int. Endod. J. 2017, 50, e40-e51. [CrossRef] [PubMed]

37. Okiji, T.; Yoshiba, K. Reparative Dentinogenesis Induced by Mineral Trioxide Aggregate: A Review from the Biological and Physicochemical Points of View. Int. J. Dent. 2009, 2009, 1-12. [CrossRef] [PubMed]

38. Watts, A.; Paterson, R.C. Initial biological testing of root canal sealing materials-A critical review. J. Dent. 1992, 20, $259-265$. [CrossRef]

39. Stanford, J.W. Recommended standard practices for biological evaluation of dental materials. Federation Dentaire International, Commission of Dental Materials, Instruments, Equipment and Therapeutics. Int. Dent. J. 1980, 30, 140-188. 